\title{
Rheological properties of flaxseed meal and soybean protein isolate blend by extrusion
}

\author{
Li Siqin ${ }^{1}$, Wu Min ${ }^{1 *}$, Zhao Donglin², Liu Yi ${ }^{1}$, Sun Yang ${ }^{1}$, Li Dong ${ }^{1}$ \\ (1. College of Engineering, China Agricultural University, Beijing 100083, China; \\ 2. Chinese Academy of Agricultural Mechanization Sciences, Beijing 100083, China)
}

\begin{abstract}
The rheological properties of flaxseed meal (FM) and Soybean Protein Isolate (SPI) extruded by the two-screw extruder under different processing conditions were investigated. Moisture, temperature, screw speed and SPI concentration were the four major factors for the extrusion process. The rheological properties of extruded products were calculated by steady state flow test, frequency sweep test and creep test. All the samples showed shear-thinning effect that is to say their apparent viscosities decreased with the increases of shear rate. The data fitted well to Power Law model. It was found that both the storage $\left(G^{\prime}\right)$ and loss modulus increased as the rise in the angular frequency $(w)$, which also fitted well to Power Law model. The creep-recovery behavior of the samples fitted well to Burger's model. In addition, the temperature had no significant effect on the creep recovery rate of the samples.
\end{abstract}

Keywords: flaxseed meal (FM), soybean protein isolate (SPI), extrusion, rheological properties

DOI: $10.25165 /$ j.ijabe.20171004.2734

Citation: Li S Q, Wu M, Zhao D L, Liu Y, Sun Y, Li D. Rheological properties of flaxseed meal and soybean protein isolate blend by extrusion. Int J Agric \& Biol Eng, 2017; 10(4): 224-233.

\section{Introduction}

Flaxseed has been cultivated both as fiber and oilseed crops $^{[1,2]}$. Canada is regarded as the biggest producer of flaxseed with $40 \%$ of the total production all over the world. Following Canada, China ranks second in the production of flaxseed, taking up $20 \%$ of the world

\section{Received date: 2016-07-28 Accepted date: 2017-03-01}

Biographies: Li Siqin, Graduate student, research interest: food science and engineering, Email: 583513521@qq.com; Zhao Donglin, Senior Engineer, research interest: agricultural product processing engineering, Email: ZDL799@126.com; Liu Yi, PhD candidate, research interest: food engineer, flaxseed based processing technologies, Email: yiliu@cau.edu.cn; Sun Yang, Graduate student, research interest: food science and engineering, Email: causunyang@163.com; Li Dong, PhD, Professor, research interest: drying technology, agriculture engineering, Email: dongle@cau.edu.cn.

*Corresponding author: Wu Min, PhD, Assistant Professor, research interest: food science and engineering, drying technology. College of Engineering, China Agricultural University, P. O. Box 50, No.17 Qinghua Donglu, Beijing 100083, China. Tel/Fax: +86-10-62736883, Email: minwu@cau.edu.cn. production. Traditionally, flaxseed is mainly used in industrial applications for flaxseed oil. Flaxseed meal (FM) is just the by-product of flaxseed after oil solvent extraction from seeds or seeds squeezing ${ }^{[3]}$. Although as a residue of flaxseed, it still has relatively high protein concentration $^{[4]}$. In most cases, FM is mainly applied to a limited extent as animal feed as a cheaper material, particularly for ruminants ${ }^{[3,5]}$. Therefore, the nutrition of FM, especially the protein component, was not utilized well in a large scale.

Extrusion is a high-temperature, short-time process in which moistened, expansive, starchy food materials are plasticized and cooked in a tube by a combination of moisture, pressure, temperature and mechanical shear, resulting in molecular transformation and chemical reaction ${ }^{[6]}$. As one of common food-processing techniques, extrusion has advantages over other methods in continuous process with high productivity and significant nutrient retention, owing to the high temperature and short time required ${ }^{[7]}$. Due to such merits, extrusion technology is widely used in food 
industry. Soybean is a low-cost and high quality protein source and it has been widely investigated as raw material for extrusion. Most previous studies have paid more attention to the chemical and physical properties of extrusion of soybean protein isolate (SPI). Chen et al. ${ }^{[8]}$ investigated the chemical cross-linking and molecular aggregation of SPI during extrusion cooking at low and high moisture contents. The influence of specific mechanical energy on the physicochemical properties of texturized soy protein during high-moisture extrusion cooking was studied by Kaushik ${ }^{[9]}$.

FM is a by-product of linseed after de-oiling, the content of crude protein in linseed meal was 32\%-36\%. However, FM has often got limited use as a residue of flaxseed for its composition has anti-nutritional factors. In the extrusion process, if we mix different kinds of plant protein materials in a certain proportion, we can improve the quality and nutritional value of extruded products $^{[10]}$. In order to make complete use of nutritional flaxseed protein, the objective of the research was to explore the rheological properties of FM and SPI mixture to provide basic information for its further application in food industry.

\section{Materials and methods}

\subsection{Materials}

FM, with $4.15 \%$ water content, $35.39 \%$ protein (TecatorKjeltec Auto 2300 Analyzer, protein factor: 6.25, Kjeltec $^{\text {TM }}$ 2300, Foss, Sweden), and $7.83 \%$ lipids (Soxhlet standard extraction mode, B-811, BüchiLabortechnik AG, Switzerland), was purchased from Shanxi Province, China. SPI, with $4.67 \%$ water content, $81.89 \%$ protein, and $4.98 \%$ lipids, was purchased from Beijing, China. The approximate composition of FM and SPI flour is shown in Table 1.

Table 1 Composition of FM and SPI

\begin{tabular}{cccc}
\hline Raw samples & Moisture & Protein & Fat \\
\hline FM & 4.15 & 35.39 & 7.83 \\
SPI & 4.67 & 81.89 & 4.98 \\
\hline
\end{tabular}

\subsection{Mixture preparation before extrusion}

FM is a by-product of flaxseed after de-oiling. Its state is flaky. Before extrusion, FM is crushed by the grinder (FW100, Tianjin Taisite Instrument Co., Ltd, Tianjin, China) and put into the riddler (200, Xinxiang Mingyang Screening Machinery Co., Ltd, Xinxiang, China) to remove the impurities.

\subsection{Experiment design}

The single factor experiment method was used to get extrusion products under different processing conditions. The interaction between different extrusion conditions was not considered. In this experiment, barrel temperature, moisture, screw speed and SPI concentration were the most important factors. The single factor experiment design is shown in Table 2.

Table 2 Design for single-factor experiments

\begin{tabular}{|c|c|c|c|c|}
\hline \multirow{2}{*}{ Run } & \multicolumn{4}{|c|}{ Four different factors } \\
\hline & $\begin{array}{c}\text { Temperature } \\
{ }^{\circ} \mathrm{C}\end{array}$ & $\begin{array}{c}\text { Moisture } \\
\quad / \%\end{array}$ & $\begin{array}{l}\text { Screw speed } \\
\quad / \mathrm{r} \cdot \mathrm{min}^{-1}\end{array}$ & $\begin{array}{l}\text { SPI concentration } \\
/ \%\end{array}$ \\
\hline 1 & 120 & 40 & 16 & 20 \\
\hline 2 & 130 & 40 & 16 & 20 \\
\hline 3 & 140 & 40 & 16 & 20 \\
\hline 4 & 150 & 40 & 16 & 20 \\
\hline 5 & 160 & 40 & 16 & 20 \\
\hline 6 & 170 & 40 & 16 & 20 \\
\hline 7 & 150 & 35 & 16 & 20 \\
\hline 8 & 150 & 45 & 16 & 20 \\
\hline 9 & 150 & 50 & 16 & 20 \\
\hline 10 & 150 & 55 & 16 & 20 \\
\hline 11 & 150 & 40 & 12 & 20 \\
\hline 12 & 150 & 40 & 14 & 20 \\
\hline 13 & 150 & 40 & 18 & 20 \\
\hline 14 & 150 & 40 & 20 & 20 \\
\hline 15 & 150 & 40 & 16 & 10 \\
\hline 16 & 150 & 40 & 16 & 15 \\
\hline 17 & 150 & 40 & 16 & 25 \\
\hline 18 & 150 & 40 & 16 & 30 \\
\hline
\end{tabular}

\subsection{Extrusion process}

Extrusion process was performed in the co-rotating twin-screw extruder (DS30-III, Shandong Saixin Machinery Co., Ltd, Shandong, China). The diameter of screw is $32 \mathrm{~mm}$, and the twin-screw's barrel has length of $600 \mathrm{~mm}$. Consequently the ratio of length to diameter is 18.75. FM and SPI were mixed evenly under different conditions (moisture, temperature, screw speed and ratio of flaxseed to SPI) and put into the extruder to make extrusion products. Then the extruded products were dried under room temperature for $24 \mathrm{~h}$.

\subsection{Samples preparation}

The extruded products were crushed and then put through the 80 mesh sieve. The obtained screened 
products were dried in the air dry oven (Shanghai Yiheng Science Instrument Co., Ltd, Shanghai, China). The samples were put into the deionized water as the ratio of 5:1 and were stirred evenly. The samples were sealed for $1 \mathrm{~h}$ in order to minimize water loss and keep water balanced.

\subsection{Rheological measurements}

Rheological properties of samples were measured by the rheometer (AR2000ex, TA Instrument Ltd, US). Aluminum parallel plate geometry $(40 \mathrm{~mm}$ diameter, $1 \mathrm{~mm}$ gap) was chosen. Temperature was set at $25^{\circ} \mathrm{C}$ by a Peltier unit attached with a water circulating system.

In order to prevent water loss during the experiment, a thin layer of silicone oil was added on the surface of samples. In addition, the linear viscoelastic region of samples (data not shown) was measured by strain sweep test under $1 \mathrm{~Hz}$ to get appropriate experiment conditions. The rheological properties of samples, including storage modulus $\left(G^{\prime}\right)$, loss modulus $\left(G^{\prime \prime}\right)$ and loss tangent $\left(\tan \delta=G^{\prime \prime} / G^{\prime}\right)$, were measured within the linear viscoelastic region (LVR) that have been acquired in the previous step. All the samples were left $2 \mathrm{~min}$ before testing to eliminate the mechanic influence of adding samples. Each sample was measured in triplicate.

\subsubsection{Steady state flow test}

The steady shear tests were performed over the shear rate range of $0.01-1 \mathrm{~s}^{-1}$ to measure the impact of shear rate on apparent viscosity of samples.

\subsubsection{Frequency sweep test}

The frequency sweep tests were carried out at the angular frequency range of $0-50 \mathrm{rad} / \mathrm{s}$ with the LVR for all the samples.

\subsubsection{Creep test}

During the creep tests, an instantaneous stress of $0.3 \mathrm{~Pa}$ was applied to the samples for $2 \mathrm{~min}$. Then the stress was instantly removed at the end of the creep stage and the strain recovery of samples was recorded for $2 \mathrm{~min}$.

\subsection{Rheological model}

\subsubsection{Steady state flow test}

The experimental apparent viscosity versus shear rate was determined by fitting Power Law model (Equation (1)), which is commonly used in simulating steady shear properties of non-Newtonian liquids ${ }^{[11]}$. The Power Law Equation is shown as follows.

$$
\tau=K \dot{\gamma}^{n}
$$

where, $\tau$ is the shear stress $(\mathrm{Pa}) ; \dot{\gamma}$ is the shear rate $\left(\mathrm{s}^{-1}\right)$; $K$ is the consistency coefficient $\left(\mathrm{Pa} \mathrm{s}^{n}\right) ; n$ is known as the flow behavior index (dimensionless).

\subsubsection{Frequency sweep test}

The angular frequency $(w)$ dependence of storage modulus $G^{\prime}$ and loss modulus $G^{\prime \prime}$ were determined by fitting Power Law model, which are expressed as follows:

$$
\begin{aligned}
& G^{\prime}=K^{\prime} w^{n^{\prime \prime}} \\
& G^{\prime \prime}=K^{\prime \prime} w^{n^{\prime \prime}}
\end{aligned}
$$

where, $K^{\prime}$ and $K^{\prime \prime}$ are the Power Law constants of samples, $n^{\prime}$ and $n^{\prime \prime}$ are known as the frequent exponent. $n^{\prime}$ and $n^{\prime \prime}$ can provide useful information about the viscoelastic nature of food materials ${ }^{[12]}$. $G^{\prime}$ is a measure of the energy stored and subsequently released per cycle of deformation per unit volume. It is the property that relates to the molecular events of elastic nature. $G^{\prime \prime}$ is a measure of the energy dissipated as heat per cycle of deformation per unit volume. $G^{\prime \prime}$ is the property that relates to the molecular events of viscous nature ${ }^{[13]}$.

\subsubsection{Creep test}

The relationship between strain $(\varepsilon(t))$ and time $(t)$ was fitted to Burger's model. The equation is shown as follows:

$$
\begin{gathered}
\varepsilon(t)=\frac{\sigma_{0}}{E_{1}}+\frac{\sigma_{0}}{\eta_{1}} t+\frac{\sigma_{0}}{E_{2}}\left(1-\exp \left(-\frac{t}{\tau_{2}}\right)\right) \\
\tau_{2}=\frac{\eta_{2}}{E_{2}}
\end{gathered}
$$

where, $E_{1}$ is the instantaneous elastic modulus, $\mathrm{Pa}$; $E_{2}$ is the retarded elastic modulus, $\mathrm{Pa} ; \eta_{1}$ is the viscosity coefficient $(\mathrm{Pa} \cdot \mathrm{s})$ related to viscous flow and reflects the biggest viscosity of samples under small deformation tests; $\tau_{2}$ is the retarded time (s), reflecting the time required for the applied stress to decrease to $1 / e$ of its initial value under constant deformation (Viscoelastic characterization of gum Arabic and maize starch mixture using the Maxwell model); $\sigma_{0}$ is the constant stress during deformation.

Creep recovery rate $(\%)$ is used to describe the recovery percentage of the extrusion product which is calculated as follows. 


$$
\text { Creep recovery rate }=\frac{\varepsilon_{T}-\varepsilon_{V}}{\varepsilon_{T}} \times 100 \%
$$

where, $\varepsilon_{T}$ is the total strain; $\varepsilon_{V}$ represents the permanent strain, caused by vicious flow.

\subsection{Statistical analysis}

All rheological experiments were carried out in triplicate. The test data were recorded as the measured values standard deviation. All the rheological data were obtained from TA Rheology Advantage Data Analysis software V 5.4.7 (TA Instruments Ltd., Crawley, UK). The Duncan's multiple test was used to analyze significant differences of experimental data by SPSS 18.0 (SPSS Inc., Chicago, USA). The significance level is 0.05 .

\section{Results and discussion}

\subsection{Steady state flow test of extruded products}

Figure 1 shows that moisture significantly influenced
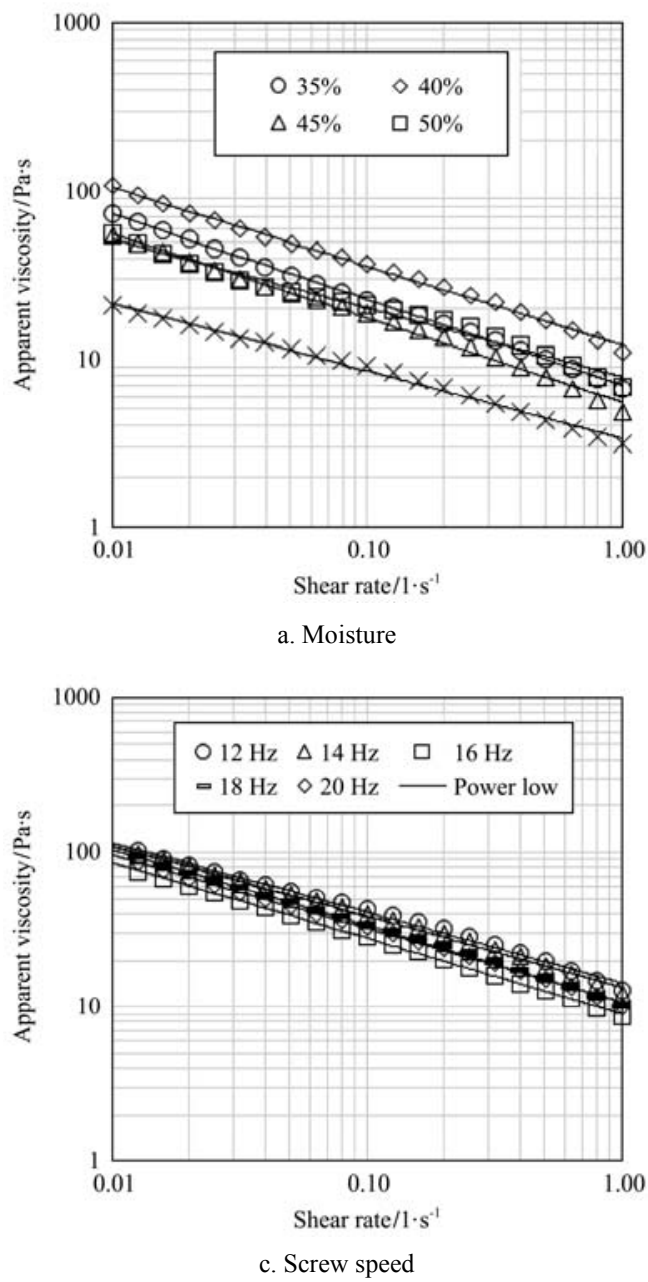

the apparent viscosity of different extrudate. As seen from Figure 1, the apparent viscosity of all the samples decreased with the increasing in the shear rate, which suggested that the samples exhibited non-Newtonian behavior. It was clearly observed that all the data fitted well to the Power Law model (correlation coefficients were higher than 0.985). All the samples show the shear thinning behavior. Similar research results were also found in the research of Wu and Pérez ${ }^{[14,15]}$.

When the moisture was $40 \%$, the sample exhibited the highest apparent viscosity compared to others. However, a continuous increase in moisture induced a decrease in the apparent viscosity of samples. This might be attributed to the fact that excessive water prevented the little molecule from being aggregated into high molecule, which played a negative role in extrusion between raw materials.
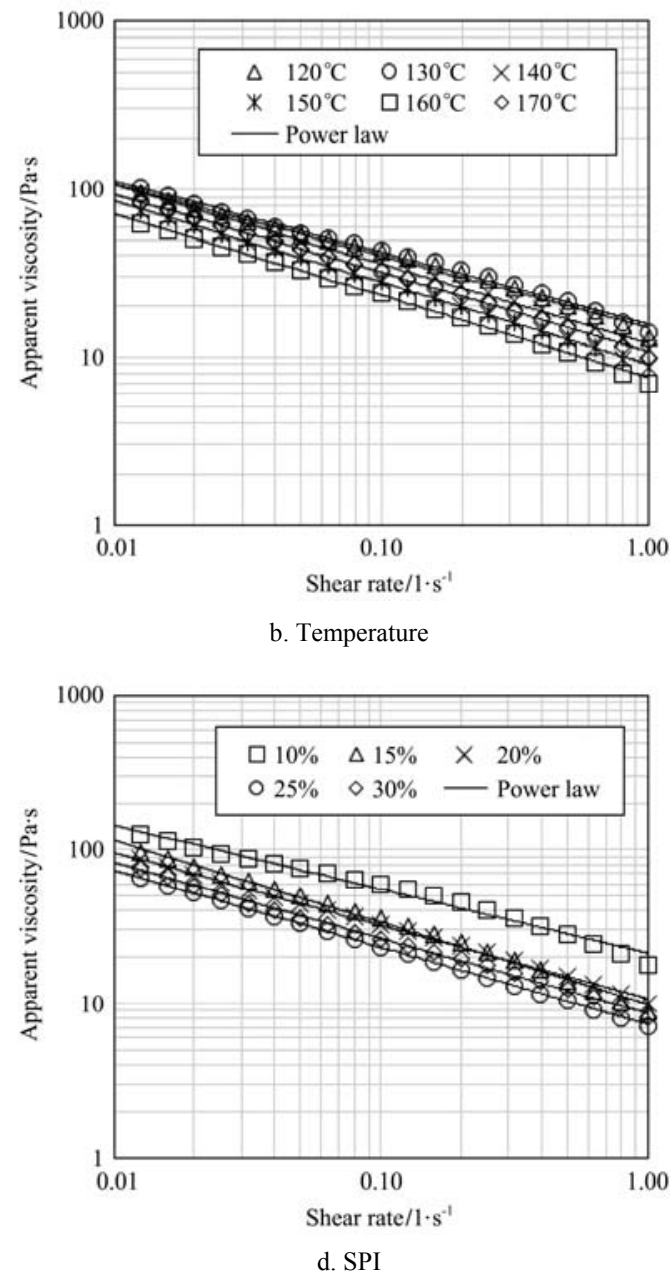

Note: Symbols indicate the experimental data and the straight lines represent the Power Law model.

Figure 1 Effect of different extrusion conditions on the apparent viscosity of extruded products

It is observed from Figure $1 \mathrm{~b}$ that when the initial temperature increased, the higher temperature would lead to the reduction in viscosity. Flaxseed gum existing in raw materials is a kind of polysaccharide. According to 
Oomah $^{[16]}$, the loss in viscosity may be caused by the polysaccharides. The high molecular was comparatively changed into low molecular weight or monosaccharide during the extrusion process. Meanwhile, increased temperature also facilitated the Maillard reaction ${ }^{[17]}$. However, the excessive would result in the reduction in viscosity.

According to Figure 1c, when the screw speed was the lowest value, the sample exhibited highest apparent viscosity. As screw speed increased, the shear force of extruder also became larger, intensifying the degradation of insoluble fiber. However, the residence time in the extruder also decreased with the rise in screw speed. With these two opposite effects, excessive temperature leaded to the increase in apparent viscosity after the lowest one. Therefore, certain screw speed can promote the degradation of flax fiber to the greatest degree.

The apparent viscosity of samples with SPI still decreased with the increase of shear rate (Figure 1d). When the SPI concentration increased from $10 \%$ to $25 \%$, the apparent viscosity of samples decreased correspondingly. This might be attributed to the interaction between SPI and FM. The SPI facilitate the compact textured structure of samples. But a continuous increase of SPI would lead to a slight rise in apparent viscosity.

Table 3 shows parameters of steady shear flow for textured products at different processing conditions. It was clearly observed from Table 3 that all the data fitted well to the Power Law model (correlation coefficients were higher than 0.985).

\subsection{Frequency sweep test of extruded products}

3.2.1 Effect of moisture on dynamic rheological properties of paste

According to Figure 2, both storage modulus $\left(G^{\prime}\right)$ and loss modulus $\left(G^{\prime \prime}\right)$ of all the samples increased as the angular frequency increased. The results were in good agreement with other types of cereal-based pastes ${ }^{[18]}$. All the data fitted well to the Power Law model (correlation coefficients were higher than 0.980). When the moisture increased from $35 \%$ to $50 \%$ as Figure 2 and Table 4 shown, there is no significant difference between $K^{\prime}$ and $K^{\prime \prime}$. $K^{\prime}$ and $K^{\prime \prime}$ show highest values when moisture is $55 \%$ due to the fact that water weakens the degradation of fibers and some high molecular and increases the water absorption of samples as a plasticizer. The storage modulus $G^{\prime}$ is higher than loss modulus $G^{\prime \prime}$ $\left(G^{\prime}>G^{\prime \prime}\right)$ suggesting that the samples showed more elastic property.

Table 3 Parameters of steady shear flow for textured products at different processing conditions*

\begin{tabular}{|c|c|c|c|}
\hline Factors & $K / \mathrm{Pa} \cdot \mathrm{s}^{n}$ & $n$ & $R^{2}$ \\
\hline \multicolumn{4}{|c|}{ Temperature $/{ }^{\circ} \mathrm{C}$} \\
\hline 120 & $15.45 \pm 0.48^{\mathrm{b}}$ & $0.588 \pm 0.011^{\mathrm{b}}$ & 0.997 \\
\hline 130 & $15.78 \pm 1.02^{\mathrm{b}}$ & $0.588 \pm 0.012^{\mathrm{b}}$ & 0.997 \\
\hline 140 & $11.67 \pm 0.40^{\mathrm{a}}$ & $0.520 \pm 0.009^{\mathrm{a}}$ & 0.997 \\
\hline 150 & $10.79 \pm 1.32^{\mathrm{a}}$ & $0.528 \pm 0.002 \mathrm{a}$ & 0.999 \\
\hline 160 & $10.38 \pm 2.13^{\mathrm{a}}$ & $0.528 \pm 0.007^{\mathrm{a}}$ & 0.999 \\
\hline 170 & $12.41 \pm 1.32^{\mathrm{a}}$ & $0.524 \pm 0.028^{\mathrm{a}}$ & 0.999 \\
\hline \multicolumn{4}{|c|}{ Moisture/\% } \\
\hline 35 & $6.49 \pm 0.52^{b}$ & $0.496 \pm 0.007^{\mathrm{a}}$ & 0.999 \\
\hline 40 & $10.79 \pm 1.32^{\mathrm{c}}$ & $0.528 \pm 0.002^{\mathrm{a}}$ & 0.999 \\
\hline 45 & $5.96 \pm 0.17^{\mathrm{ab}}$ & $0.529 \pm 0.045^{\mathrm{a}}$ & 0.996 \\
\hline 50 & $9.15 \pm 1.43^{\mathrm{c}}$ & $0.607 \pm 0.027^{\mathrm{b}}$ & 0.985 \\
\hline 55 & $4.53 \pm 0.87^{\mathrm{a}}$ & $0.661 \pm 0.037^{\mathrm{c}}$ & 0.994 \\
\hline \multicolumn{4}{|c|}{ Screw speed/Hz } \\
\hline 12 & $12.63 \pm 2.04^{\mathrm{a}}$ & $0.531 \pm 0.039^{\mathrm{a}}$ & 0.998 \\
\hline 14 & $13.17 \pm 1.16^{\mathrm{a}}$ & $0.554 \pm 0.005^{\mathrm{ab}}$ & 0.999 \\
\hline 16 & $10.79 \pm 1.32^{\mathrm{a}}$ & $0.528 \pm 0.002^{\mathrm{a}}$ & 0.999 \\
\hline 18 & $11.43 \pm 1.57^{\mathrm{a}}$ & $0.521 \pm 0.009^{\mathrm{a}}$ & 1.000 \\
\hline 20 & $13.45 \pm 0.51^{\mathrm{a}}$ & $0.574 \pm 0.017^{\mathrm{b}}$ & 0.996 \\
\hline \multicolumn{4}{|c|}{ SPI concentration $/ \%$} \\
\hline 10 & $22.79 \pm 1.65^{\mathrm{c}}$ & $0.639 \pm 0.024^{\mathrm{b}}$ & 0.992 \\
\hline 15 & $11.07 \pm 0.66^{\mathrm{b}}$ & $0.500 \pm 0.010^{\mathrm{a}}$ & 0.999 \\
\hline 20 & $10.79 \pm 1.32^{\mathrm{ab}}$ & $0.528 \pm 0.002^{\mathrm{a}}$ & 0.999 \\
\hline 25 & $8.90 \pm 1.16^{\mathrm{ab}}$ & $0.504 \pm 0.003^{\mathrm{a}}$ & 1.000 \\
\hline 30 & $8.80 \pm 0.54^{\mathrm{a}}$ & $0.514 \pm 0.022^{\mathrm{a}}$ & 0.998 \\
\hline
\end{tabular}

Note: *Values represent the mean \pm standard deviation of triplicate tests; values in a column with different superscripts were significantly different $(p<0.05)$.

3.2.2 Effect of temperature on dynamic rheological properties of paste

The $G^{\prime}$ and $G^{\prime \prime}$ also went to rise with the increase of angular frequency (Figure 3). All these data were well applied to Power Law model (correlation coefficients were higher than 0.980). When the temperature increased from $120^{\circ} \mathrm{C}$ to $170^{\circ} \mathrm{C}, K^{\prime}$ firstly decreased to the lowest value (Table 4), and then went to rise. $n^{\prime}$ showed an opposite varying trend. The reduction in $K^{\prime}$ was probably due to the increase in degradation of water insoluble fibers or else. However a continuous temperature rising inhibited these reactions. 
3.2.3 Effect of screw speed on dynamic rheological properties of paste

Both $G^{\prime}$ and $G^{\prime \prime}$ of all samples increased with the increment in angular frequency (Figure 4). All the data fitted well to Power Law model (correlation coefficients were higher than 0.988). The increase in screw speed had no significant difference in $K^{\prime}$ and $K^{\prime \prime}$ (Table 4).

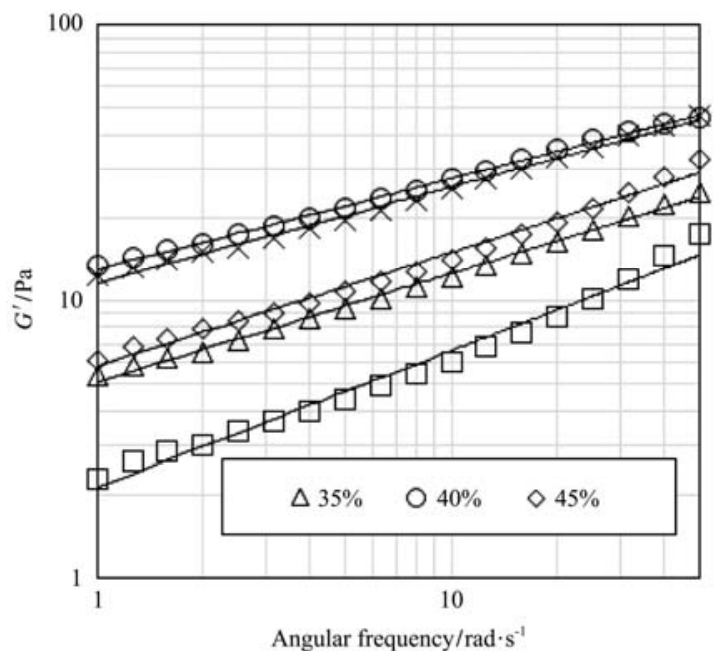

a. Effect of moisture on the storage modulus $\left(G^{\prime}\right)$
The viscoelastic modulus of the samples extruded at lower screw speed was higher compared to that at higher screw speed. It is caused by the generation of high mechanical stresses and longer residence time at these screw speed, which helped the low molecular aggregated into high molecular. Similar research results were also found in the research of Wu et al. ${ }^{[19]}$

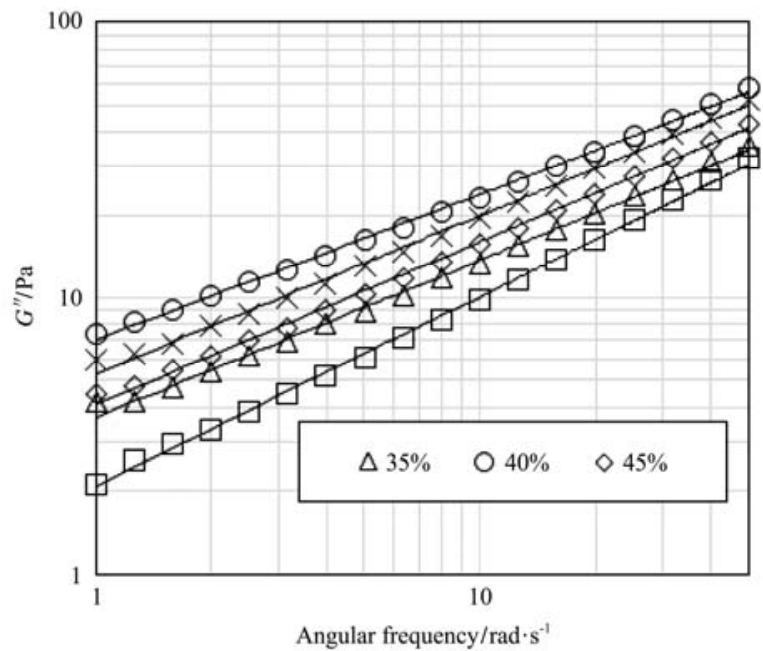

b. Effect of moisture on the loss storage $\left(G^{\prime \prime}\right)$

Note: Symbols indicate the experimental data and the straight lines represent the Power Law model.

Figure 2 Effect of moisture on the storage modulus $\left(G^{\prime}\right)$ and loss storage $\left(G^{\prime \prime}\right)$ of the samples

Table 4 Effect of extrusion conditions on $K^{\prime}, K^{\prime \prime}, n^{\prime}$ and $n^{\prime \prime}$ in the Power Law model ${ }^{*}$

\begin{tabular}{|c|c|c|c|c|c|c|}
\hline Factors & $K^{\prime}$ & $n^{\prime}$ & $R^{2}$ & $K^{\prime \prime}$ & $n^{\prime \prime}$ & $R^{2}$ \\
\hline \multicolumn{7}{|c|}{ Temperature $/{ }^{\circ} \mathrm{C}$} \\
\hline 120 & $17.99 \pm 1.22^{\mathrm{c}}$ & $0.315 \pm 0.031^{\mathrm{a}}$ & 0.996 & $9.29 \pm 0.28^{\mathrm{b}}$ & $0.514 \pm 0.005^{\mathrm{a}}$ & 0.999 \\
\hline 130 & $19.15 \pm 2.64^{\mathrm{c}}$ & $0.326 \pm 0.035^{\mathrm{a}}$ & 0.995 & $10.03 \pm 0.55^{\mathrm{b}}$ & $0.510 \pm 0.001^{\mathrm{a}}$ & 0.999 \\
\hline 140 & $13.33 \pm 0.78^{\mathrm{b}}$ & $0.347 \pm 0.009^{\mathrm{a}}$ & 0.998 & $7.41 \pm 0.36^{\mathrm{a}}$ & $0.535 \pm 0.006^{\mathrm{b}}$ & 0.999 \\
\hline 150 & $11.58 \pm 1.41^{\mathrm{ab}}$ & $0.322 \pm 0.012^{\mathrm{a}}$ & 0.996 & $6.50 \pm 0.93^{\mathrm{a}}$ & $0.553 \pm 0.012^{\mathrm{c}}$ & 0.999 \\
\hline 170 & $12.40 \pm 1.62^{\mathrm{b}}$ & $0.355 \pm 0.071^{\mathrm{a}}$ & 0.991 & $7.43 \pm 0.79^{\mathrm{a}}$ & $0.549 \pm 0.007^{\mathrm{c}}$ & 0.999 \\
\hline \multicolumn{7}{|c|}{ Moisture/\% } \\
\hline 35 & $5.25 \pm 0.47^{\mathrm{a}}$ & $0.437 \pm 0.027^{\text {bc }}$ & 0.996 & $3.95 \pm 0.46^{\mathrm{a}}$ & $0.597 \pm 0.003^{\mathrm{ab}}$ & 0.999 \\
\hline 40 & $11.59 \pm 1.41^{\mathrm{a}}$ & $0.322 \pm 0.012^{\mathrm{a}}$ & 0.996 & $6.50 \pm 0.93^{\mathrm{a}}$ & $0.553 \pm 0.012^{\mathrm{a}}$ & 0.999 \\
\hline 45 & $4.90 \pm 0.92^{\mathrm{a}}$ & $0.457 \pm 0.070^{\mathrm{c}}$ & 0.989 & $3.68 \pm 0.29^{\mathrm{a}}$ & $0.622 \pm 0.008^{\mathrm{b}}$ & 1.000 \\
\hline 50 & $9.01 \pm 2.03^{\mathrm{a}}$ & $0.431 \pm 0.060^{\mathrm{bc}}$ & 0.980 & $5.68 \pm 0.73^{\mathrm{a}}$ & $0.591 \pm 0.007^{\mathrm{ab}}$ & 0.999 \\
\hline \multicolumn{7}{|c|}{ Screw speed/Hz } \\
\hline 12 & $11.24 \pm 1.25^{\mathrm{a}}$ & $0.427 \pm 0.016^{\mathrm{b}}$ & 0.988 & $7.39 \pm 0.87^{\mathrm{a}}$ & $0.536 \pm 0.006^{\mathrm{a}}$ & 0.999 \\
\hline 14 & $11.91 \pm 2.55^{\mathrm{a}}$ & $0.384 \pm 0.060^{\mathrm{b}}$ & 0.991 & $7.24 \pm 0.98^{\mathrm{a}}$ & $0.537 \pm 0.007^{\mathrm{a}}$ & 0.999 \\
\hline 16 & $11.59 \pm 1.41^{\mathrm{a}}$ & $0.322 \pm 0.012^{\mathrm{a}}$ & 0.996 & $6.50 \pm 0.93^{\mathrm{a}}$ & $0.553 \pm 0.012^{\mathrm{bc}}$ & 0.999 \\
\hline 18 & $9.46 \pm 0.93^{\mathrm{a}}$ & $0.408 \pm 0.017^{\mathrm{b}}$ & 0.996 & $6.31 \pm 0.91^{\mathrm{a}}$ & $0.558 \pm 0.011^{\mathrm{c}}$ & 0.999 \\
\hline 20 & $12.52 \pm 1.08^{\mathrm{a}}$ & $0.402 \pm 0.018^{\mathrm{b}}$ & 0.991 & $7.83 \pm 0.33^{\mathrm{a}}$ & $0.538 \pm 0.007^{\mathrm{ab}}$ & 0.999 \\
\hline \multicolumn{7}{|c|}{ SPI concentration $/ \%$} \\
\hline 10 & $29.33 \pm 4.44^{\mathrm{c}}$ & $0.290 \pm 0.020^{\mathrm{a}}$ & 0.997 & $13.70 \pm 1.81^{\mathrm{b}}$ & $0.482 \pm 0.008^{\mathrm{a}}$ & 0.998 \\
\hline 15 & $8.11 \pm 2.05^{\mathrm{ab}}$ & $0.460 \pm 0.095^{\mathrm{b}}$ & 0.989 & $6.42 \pm 0.56^{\mathrm{a}}$ & $0.584 \pm 0.005^{\mathrm{c}}$ & 1.000 \\
\hline 20 & $11.59 \pm 1.41^{\mathrm{b}}$ & $0.322 \pm 0.012^{\mathrm{a}}$ & 0.996 & $6.50 \pm 0.93^{\mathrm{a}}$ & $0.553 \pm 0.012^{\mathrm{b}}$ & 0.999 \\
\hline 25 & $5.61 \pm 2.08^{\mathrm{a}}$ & $0.511 \pm 0.116^{\mathrm{b}}$ & 0.990 & $5.08 \pm 0.90^{\mathrm{a}}$ & $0.593 \pm 0.010^{\mathrm{c}}$ & 1.000 \\
\hline 30 & $7.41 \pm 0.18^{\mathrm{ab}}$ & $0.473 \pm 0.017^{\mathrm{b}}$ & 0.983 & $5.47 \pm 0.11^{\mathrm{a}}$ & $0.560 \pm 0.003^{\mathrm{b}}$ & 0.999 \\
\hline
\end{tabular}

Note: ${ }^{*}$ Values represent the mean \pm standard deviation of triplicate tests; values in a column with different superscripts were significantly different $(p<0.05)$. 


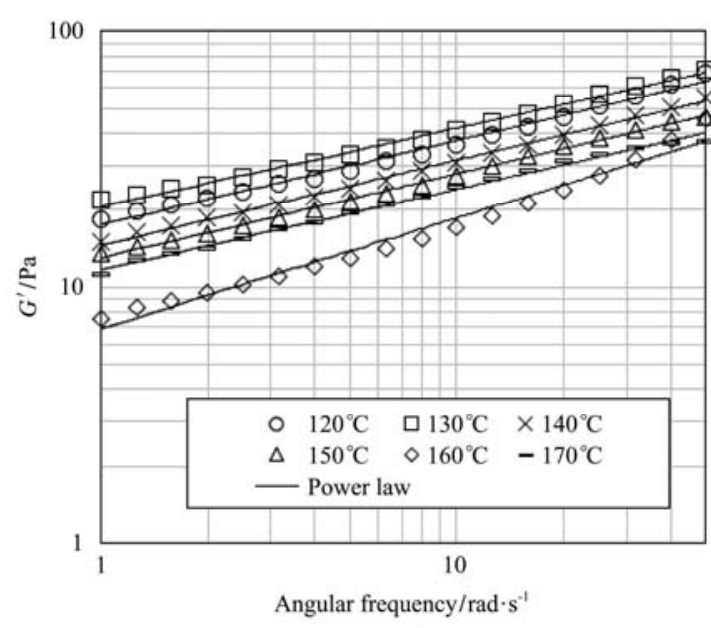

a. Effect of temperature on the storage modulus $\left(G^{\prime}\right)$

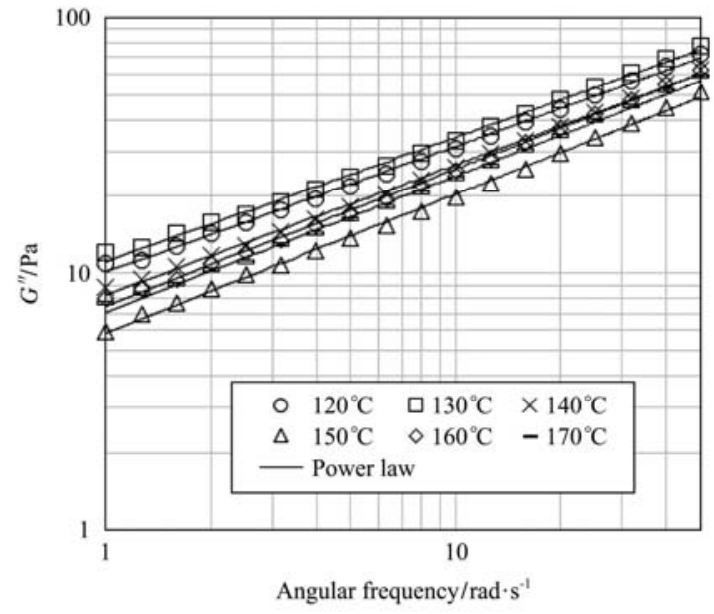

b. Effect of temperature on the loss storage $\left(G^{\prime \prime}\right)$

Note: Symbols indicate the experimental data and the straight lines represent the Power Law model.

Figure 3 Effect of temperature on the storage modulus $\left(G^{\prime}\right)$ and loss storage $\left(G^{\prime \prime}\right)$ of samples

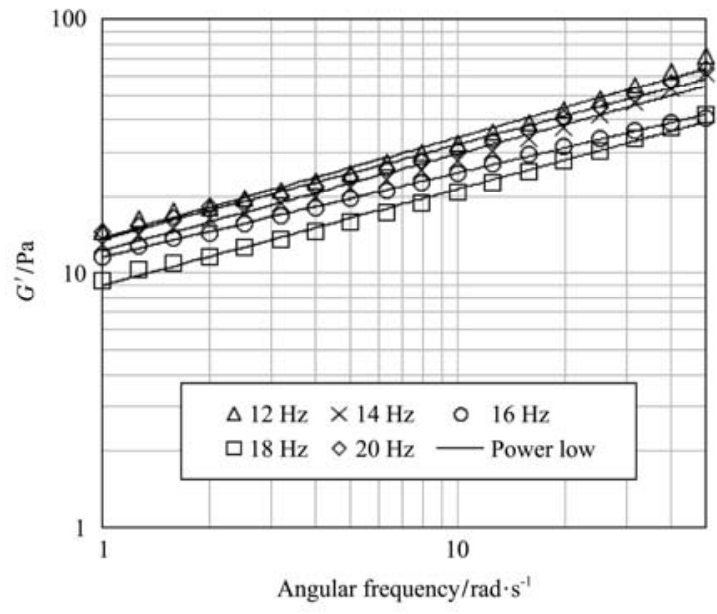

a. Effect of screw speed on the storage modulus $\left(G^{\prime}\right)$

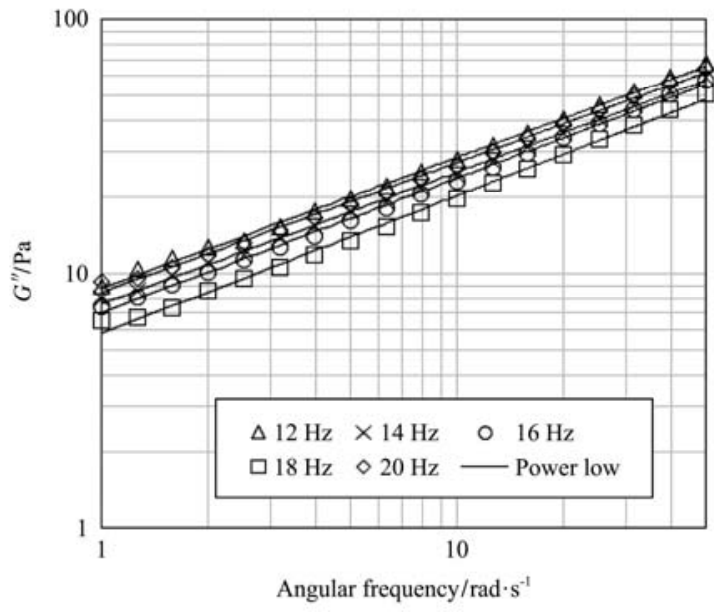

b. Effect of screw speed on the loss storage $\left(G^{\prime \prime}\right)$

Note: Symbols indicate the experimental data and the straight lines represent the Power Law model.

Figure 4 Effects of screw speed on the storage modulus $\left(G^{\prime}\right)$ and loss storage $\left(G^{\prime \prime}\right)$ of samples

\subsubsection{Effect of SPI concentration on dynamic} rheological properties of paste

The $G^{\prime}$ and $G^{\prime \prime}$ also went to rise with the increase of angular frequency. All these data was well applied to Power Law model (correlation coefficients were higher than 0.983). As seen from Figure 5, the viscoelastic modulus of samples decreased with the increase of SPI concentration from $10 \%$ to $25 \%$ and increased with further increase in SPI content to $30 \%$. When $10 \%$ SPI was added to FM, the sample showed the highest storage modulus $G^{\prime}$. The decrease in loss modulus $G^{\prime \prime}$ was caused by the fact that SPI reduced the degradation of flax fibers or other macromolecular, which weakened the viscoelastic property of samples. But with further addition of SPI, the total protein concentration of samples highly increased, which facilitated protein to aggregate and helped to form a more compatible network.

\subsection{Creep test of extruded products}

According to Figure 6, the creep test data of samples exhibited a typical viscoelastic behavior. Similar research occurred in the research about cereal dough ${ }^{[20]}$. The sample with initial moisture of $50 \%$ showed the lowest strain and the sample at 55\% moisture exhibited maximum strain and lowest recovery, suggesting that raw materials formed weak network under the condition of excessive water. The sample showed a more liquid-like network. The creep recovery of samples decreased with temperature went up and increased with further increase in temperature. The sample had greatest creep strain when temperature was $150^{\circ} \mathrm{C}$, suggesting that it had least resistance to deformation. The temperature has no significant effect on the creep recovery of sample. With 
addition of SPI, the retarded time increased and then decreased, suggesting that raw material formed a solider

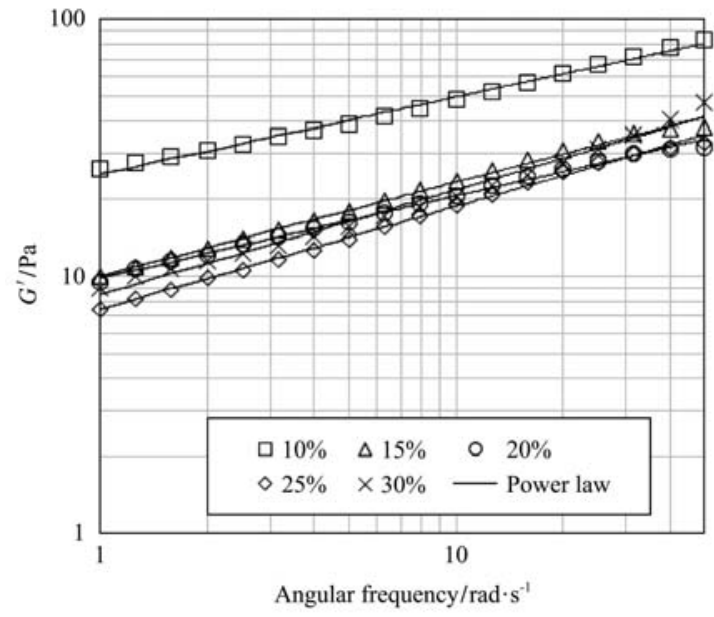

a. Effect of SPI concentration on the storage modulus $\left(G^{\prime}\right)$ network and would had a weak structure with excess SPI concentration.

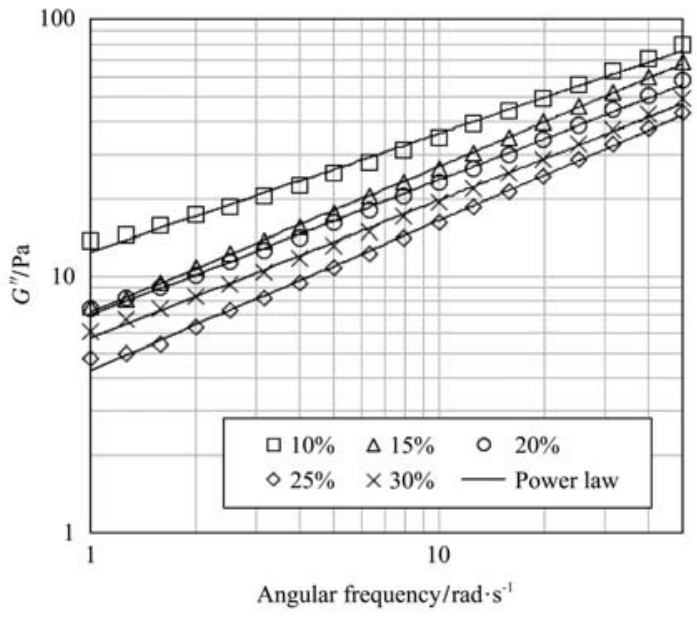

b. Effect of SPI concentration on the and loss storage $\left(G^{\prime \prime}\right)$ Note: Symbols indicate the experimental data and the straight lines represent the Power Law model.

Figure 5 Effect of SPI concentration on the storage modulus $\left(G^{\prime}\right)$ and loss storage $\left(G^{\prime \prime}\right)$ of samples

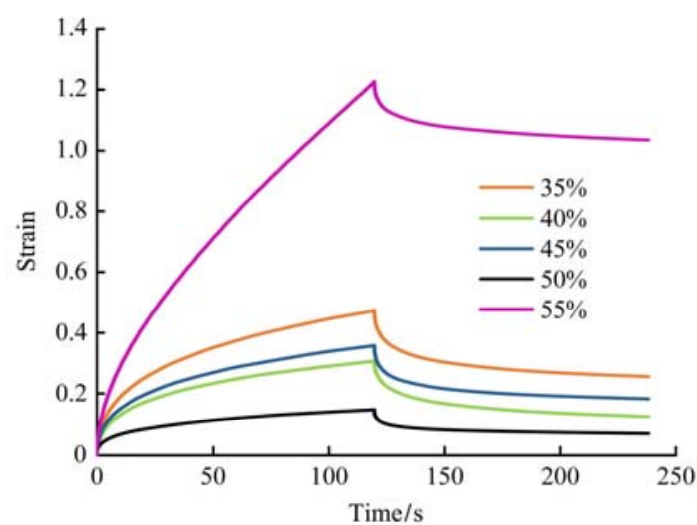

a. Moisture

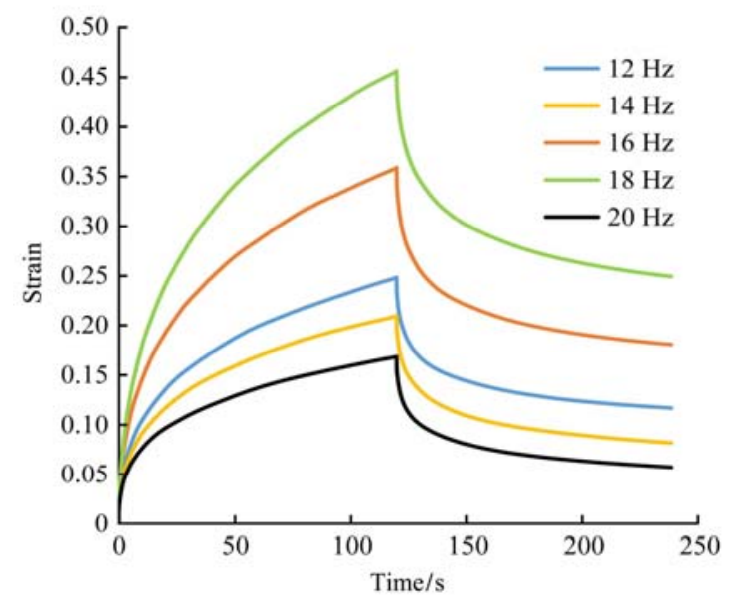

c. Screw speed

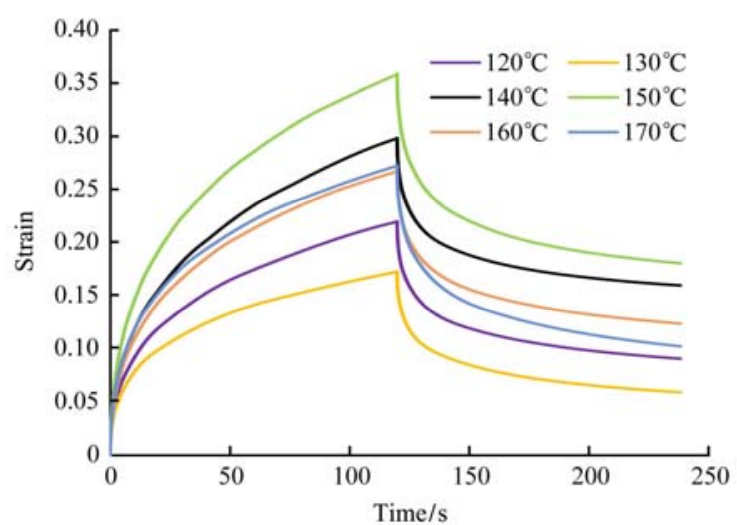

b. Temperature

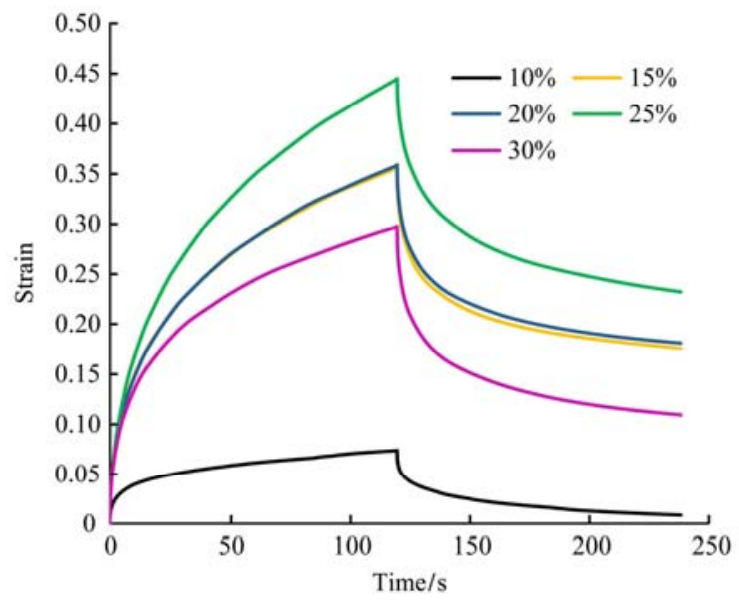

d. SPI concentration

Figure 6 Effect of different extrusion conditions on the creep-recovery behaviors of the extruded products

Parameter of Burger's model of extruded dispersions of the samples and recovery rate are presented in Table 5 . As seen from Table 5, all the creep data fitted well to Burger's model (correlation coefficients were higher than
0.981). The instantaneous elastic modulus $E_{1}$ is much greater than retarded elastic modulus $E_{2}$. Therefore, compared with retarded elastic strain $\varepsilon_{R}$ and $\varepsilon_{V}$ caused by viscous flow, the instantaneous strain $\varepsilon_{\mathrm{E}}$ is very small. 
Table 5 Parameters of Burger's model of extruded dispersions of textured products and recovery rate in creep recovery test ${ }^{*}$

\begin{tabular}{|c|c|c|c|c|c|c|}
\hline Factor & $E_{1} / \mathrm{Pa}$ & $E_{2} / \mathrm{Pa}$ & $\eta_{1} / \mathrm{Pa} \mathrm{s}$ & $\tau_{2} / \mathrm{s}$ & $R^{2}$ & Recovery $/ \%$ \\
\hline \multicolumn{7}{|c|}{ Temperature $/{ }^{\circ} \mathrm{C}$} \\
\hline 120 & $31.34 \pm 4.46^{\mathrm{c}}$ & $3.46 \pm 0.72^{\mathrm{c}}$ & $286.38 \pm 56.20^{\mathrm{bc}}$ & $4.93 \pm 0.36^{\mathrm{a}}$ & 0.991 & $0.654 \pm 0.073^{\mathrm{a}}$ \\
\hline 130 & $31.45 \pm 3.15^{\mathrm{c}}$ & $3.55 \pm 0.56^{\mathrm{c}}$ & $311.74 \pm 51.01^{\mathrm{c}}$ & $4.95 \pm 0.67^{\mathrm{a}}$ & 0.991 & $0.619 \pm 0.077^{\mathrm{a}}$ \\
\hline 140 & $25.91 \pm 1.31^{\mathrm{ab}}$ & $2.66 \pm 0.12^{\mathrm{ab}}$ & $228.15 \pm 32.98^{\mathrm{ab}}$ & $5.04 \pm 0.48^{\mathrm{a}}$ & 0.991 & $0.567 \pm 0.089^{\mathrm{a}}$ \\
\hline 150 & $22.53 \pm 0.79^{\mathrm{a}}$ & $2.03 \pm 0.13^{\mathrm{a}}$ & $179.26 \pm 18.06^{\mathrm{a}}$ & $5.88 \pm 0.13^{b}$ & 0.993 & $0.542 \pm 0.046^{\mathrm{a}}$ \\
\hline 160 & $29.46 \pm 1.42^{\mathrm{bc}}$ & $2.94 \pm 0.28^{\mathrm{bc}}$ & $260.92 \pm 39.85^{\mathrm{bc}}$ & $5.36 \pm 0.32^{\mathrm{ab}}$ & 0.992 & $0.593 \pm 0.057^{\mathrm{a}}$ \\
\hline 170 & $25.07 \pm 0.30^{\mathrm{ab}}$ & $2.41 \pm 0.05^{\mathrm{ab}}$ & $216.80 \pm 13.90^{\mathrm{ab}}$ & $5.65 \pm 0.11^{\mathrm{ab}}$ & 0.992 & $0.598 \pm 0.048^{\mathrm{a}}$ \\
\hline \multicolumn{7}{|c|}{ Moisture/\% } \\
\hline 35 & $19.33 \pm 1.06^{\mathrm{b}}$ & $1.60 \pm 0.09^{\mathrm{b}}$ & $133.87 \pm 10.51^{b}$ & $5.61 \pm 0.11^{\mathrm{b}}$ & 0.993 & $0.458 \pm 0.018^{b}$ \\
\hline 40 & $22.53 \pm 0.79^{\mathrm{c}}$ & $2.03 \pm 0.13^{\mathrm{c}}$ & $179.26 \pm 18.06^{\mathrm{b}}$ & $5.88 \pm 0.13^{\mathrm{b}}$ & 0.993 & $0.542 \pm 0.046^{\mathrm{bc}}$ \\
\hline 45 & $19.87 \pm 0.25^{\mathrm{c}}$ & $1.92 \pm 0.16^{\mathrm{c}}$ & $143.62 \pm 17.04^{\mathrm{b}}$ & $5.35 \pm 0.31^{\mathrm{b}}$ & 0.992 & $0.430 \pm 0.050^{\mathrm{b}}$ \\
\hline 50 & $35.57 \pm 3.06^{\mathrm{d}}$ & $5.07 \pm 0.21^{\mathrm{d}}$ & $459.03 \pm 66.22^{\mathrm{c}}$ & $3.22 \pm 0.20^{\mathrm{a}}$ & 0.984 & $0.599 \pm 0.070^{\mathrm{c}}$ \\
\hline 55 & $14.84 \pm 1.20^{\mathrm{a}}$ & $1.02 \pm 0.12^{\mathrm{a}}$ & $34.35 \pm 4.56^{\mathrm{a}}$ & $7.12 \pm 0.72^{\mathrm{c}}$ & 0.998 & $0.180 \pm 0.098^{\mathrm{a}}$ \\
\hline \multicolumn{7}{|c|}{ Screw speed/Hz } \\
\hline 12 & $27.98 \pm 2.03^{\mathrm{ab}}$ & $2.86 \pm 0.30^{\mathrm{c}}$ & $244.70 \pm 29.36^{\mathrm{c}}$ & $5.02 \pm 0.29^{\mathrm{a}}$ & 0.991 & $0.587 \pm 0.052^{\mathrm{ab}}$ \\
\hline 14 & $22.29 \pm 17.14^{\mathrm{ab}}$ & $3.38 \pm 0.24^{\mathrm{d}}$ & $289.54 \pm 22.75^{\mathrm{d}}$ & $4.98 \pm 0.05^{\mathrm{a}}$ & 0.991 & $0.639 \pm 0.029^{\mathrm{b}}$ \\
\hline 16 & $22.53 \pm 0.79^{\mathrm{ab}}$ & $2.03 \pm 0.13^{\mathrm{b}}$ & $179.26 \pm 18.06^{\mathrm{b}}$ & $5.88 \pm 0.13^{\mathrm{b}}$ & 0.993 & $0.542 \pm 0.046^{\mathrm{ab}}$ \\
\hline 18 & $19.18 \pm 1.66^{\mathrm{a}}$ & $1.46 \pm 0.11^{\mathrm{a}}$ & $131.31 \pm 12.76^{\mathrm{a}}$ & $6.61 \pm 0.38^{\mathrm{c}}$ & 0.994 & $0.529 \pm 0.074^{\mathrm{a}}$ \\
\hline 20 & $35.03 \pm 0.59^{\mathrm{b}}$ & $4.10 \pm 0.09^{\mathrm{e}}$ & $361.80 \pm 14.73^{\mathrm{e}}$ & $4.52 \pm 0.36^{\mathrm{a}}$ & 0.990 & $0.634 \pm 0.040^{\mathrm{b}}$ \\
\hline \multicolumn{7}{|c|}{ SPI concentration $/ \%$} \\
\hline 10 & $77.96 \pm 22.13^{b}$ & $17.54 \pm 9.43^{b}$ & $1501.27 \pm 759.92^{\mathrm{b}}$ & $2.45 \pm 0.40^{\mathrm{a}}$ & 0.981 & $0.820 \pm 0.063^{\mathrm{c}}$ \\
\hline 15 & $21.39 \pm 0.26^{\mathrm{a}}$ & $1.90 \pm 0.08^{\mathrm{a}}$ & $161.35 \pm 3.76^{\mathrm{a}}$ & $5.57 \pm 0.03^{\mathrm{bc}}$ & 0.993 & $0.491 \pm 0.013^{\mathrm{a}}$ \\
\hline 20 & $22.53 \pm 0.79^{\mathrm{a}}$ & $2.03 \pm 0.13^{\mathrm{a}}$ & $179.26 \pm 18.06^{\mathrm{a}}$ & $5.88 \pm 0.13^{\mathrm{c}}$ & 0.993 & $0.542 \pm 0.046^{\mathrm{ab}}$ \\
\hline 25 & $21.33 \pm 1.13^{\mathrm{a}}$ & $1.56 \pm 0.10^{\mathrm{a}}$ & $126.55 \pm 6.29^{\mathrm{a}}$ & $7.20 \pm 0.20^{\mathrm{d}}$ & 0.995 & $0.523 \pm 0.067^{\mathrm{ab}}$ \\
\hline 30 & $21.94 \pm 2.62^{\mathrm{a}}$ & $1.97 \pm 0.21^{\mathrm{a}}$ & $176.48 \pm 32.59^{\mathrm{a}}$ & $5.33 \pm 0.29^{\mathrm{b}}$ & 0.992 & $0.607 \pm 0.024^{\mathrm{b}}$ \\
\hline
\end{tabular}

Note: ${ }^{*}$ Values represent the mean \pm standard deviation of triplicate tests; values in a column with different superscripts were significantly different $(p<0.05)$.

\section{Conclusions}

The present study was to explore the effects of different extrusion conditions on the rheological properties of extruded flaxseed meal (FM) and soybean protein isolate (SPI). The single factor experiment was used to make different products including moisture (35\%-55\%), temperature $\left(120^{\circ} \mathrm{C}-170^{\circ} \mathrm{C}\right)$, screw speed (12-20 r/min) and SPI concentration (10\%-30\%).

The rheological properties of the extruded samples were tested by steady state flow test, frequency sweep test and creep test. The apparent viscosity, storage modulus $\left(G^{\prime}\right)$ and loss modulus $\left(G^{\prime \prime}\right)$ were modeled by Power Law Equation while the creep data fitted well to Burger's model.

The extruded samples showed shear-thinning effect, suggesting that its apparent viscosity decreased with the increase in shear rate. The storage modulus $\left(G^{\prime}\right)$ and loss modulus $\left(G^{\prime \prime}\right)$ increased with the increase in angular frequency. The temperature has no significant effect on the creep recovery of sample.

\section{Acknowledgement}

This research project was supported by the National Natural Science Foundation of China (31301593), Chinese Universities Scientific Fund (2017QC041) and Research and Development Fund for University's Doctoral Discipline of China (20130008120021).

\section{[References]}

[1] Rabetafika H N, Remoortel V V, Danthine S, Paquot M, Blecker C. Flaxseed proteins: food uses and health benefits. International Journal of Food Science \& Technology, 2011; 46(2): 221-228.

[2] Marpalle P, Sonawane S K, LeBlanc J G, Arya S S. Nutritional characterization and oxidative stability of a-linolenic acid in bread containing roasted ground flaxseed. 
LWT-Food Science and Technology, 2015; 61: 510-515.

[3] Karamać M, Kulczyk A, Sulewska K. Antioxidant activity of hydrolysates prepared from flaxseed meal proteins using pancreatin. Polish Journal of Food \& Nutrition Sciences, 2014; 64(4): 227-233.

[4] Wu M, Liu Y, Wang L J, Li D, Mao Z H. Effects of extrusion parameters on physicochemical properties of flaxseed snack and process optimization. Int J Agric \& Biol Eng, 2015; 8(5): 121-131.

[5] Oomah B D, Mazza G. Flaxseed proteins-a review. Food Chemistry, 1993; 48(2): 109-114.

[6] Shivendra S, Shirani G, Lara W. Nutritional aspects of food extrusion: a review. International Journal of Food Science \& Technology, 2007; 42(8): 916-929.

[7] Makki F. Extrusion cooking: Technologies and applications: R. Guy; Woodhead Publishing Ltd., Cambridge, UK. Food Research International, 2002; 35: 897-898.

[8] Chen F L, Wei Y M, Zhang B. Chemical cross-linking and molecular aggregation of soybean protein during extrusion cooking at low and high moisture content. LWT - Food Science and Technology, 2011; 44(4): 957-962.

[9] Kaushik P, Dowling K, Barrow C J, Adhikari B. Complex coacervation between flaxseed protein isolate and flaxseed gum. Food Research International, 2015; 72: 91-97.

[10] Akdogan H. High moisture food extrusion. International Journal of Food Science \& Technology, 1999; 34(3): 195-207.

[11] Steffe J F. Rheological methods in food process engineering. James D Steffes Home Page, East Lansing, MI: Freeman Press Inc. 1996.

[12] ÖZkan N, Xin H, Chen X D. Application of a depth sensing indentation hardness test to evaluate the mechanical properties of food materials. Journal of Food Science, 2002;
7(5): 1814-1820.

[13] Gunasekaran S, Ak M M. Dynamic oscillatory shear testing of foods- selected applications. Trends in Food Science \& Technology, 2000; 11(3): 115-127.

[14] Wu M, Liu Y, Wang L J, Li D. Effect of extrusion parameters on rheological properties, chromatism, protein solubility and microstructure of flaxseed-corn blend. Int $\mathrm{J}$ Agric \& Biol Eng, 2015; 8(6): 89-98.

[15] Pérez A A, Drago S R, Carrara C R, de Greef D M, Torres R L, González R J. Extrusion cooking of a maize/soybean mixture: factors affecting expanded product characteristics and flour dispersion viscosity. Journal of Food Engineering, 2008; 87(3): 333-340.

[16] Oomah B D, Kenaschuk E O, Cui W, Mazza G. Variation in the composition of water-soluble polysaccharides in flaxseed. Journal of Agricultural \& Food Chemistry, 2002; 43(6): 1484-1488.

[17] Wu M, Li D, Wang L J, ÖZkan N, Mao Z H. Rheological properties of extruded dispersions of flaxseed-maize blend. Journal of Food Engineering, 2010; 98(4): 480-491.

[18] Hao C C, Wang L J, Li D, ÖZkan N, Wang D C, Mao Z H. Influence of alfalfa powder concentration and granularity on rheological properties of alfalfa-wheat dough. Journal of Food Engineering, 2008; 89(2): 137-141.

[19] Wu M, Li D, Wang L J, Zhou Y G, Mao Z H. Rheological property of extruded and enzyme treated flaxseed mucilage. Carbohydrate Polymers, 2010; 80(2): 460-466.

[20] Edwards N M, Dexter J E, Scanlon M G, Cenkowski S. Relationship of creep-recovery and dynamic oscillatory measurements to durum wheat physical dough properties. Cereal Chemistry, 1999; 76(5): 638-645. 